\title{
Siberian regional policy: the past and modern problems
}

"We can see very often in Russia that some of our new problems are things which should have been solved long time ago, in the distant past, but preserved and retained for the future [...]" (Lamin, Malov 2005, p. 83).

For instance, modern problems in Siberian regional development emerging recently have strong relations in the past. According to several Russian and foreign authors (starting with the authors of The Siberian Curse: How Communist Planners Left Russia Out in the Cold, these problems came from the Soviet period of the planned abusive industrial colonization of Siberia, or even earlier, from the period of monarchy. "In the late nineteenth century, Russia's inhabitants continued to move. This time, they moved into territory with a much harsher climate and even poorer soils than Old Muscovy - across the Ural Mountains and into Siberia" (Gaddy, Hill 2003, p. 62).

But it is essentially hard to realize the entire situation about Siberia as from Moscow, or even more so, from abroad. Moreover, it is sometimes even difficult to define, for some of those researchers, where the boundary between Siberia and the Urals, or Siberia and the Far East is really located. Neither do they take into account a huge difference in territorial proportions and contrasts between different Siberian regions (for instance, from Southern to Northern, and also from Western to Eastern Siberia) as well as distances between its main cities. They can hardly imagine such things until they experience something similar in real life. So it is extremely inappropriate to use non-geographic dot method trying to solve regional problems today. In other words, all the vast area from Yekaterinburg to Anadyr can not be measured as "one size fits all", or just only by a thermometer.

The problem is really complicated, many-sided and we have to study it with open mind. In the Soviet period, the development of the North, Siberia and the Far East was not carried out by some particular scenario, as it might seem at first sight. Development was planned across the whole country, based on united strategic objectives and current capabilities. Also it must be stated that it is unfair to use the term of regional policy for the Soviet period, because of certain specific structure of a national economy that developed in the 1930s. Stalin made the choice of the absolute state-owned business as a form of realization of an ideologically-based economic model with public property for any means of production, declared earlier by Lenin. 
Hence, there was just direct distribution of productive forces inside diverse industrial ministries, which acted like a kind of monopoly corporations, but with full state participation, and which used advantages of considerable administrative resources and, indeed, the lack of direct competition in such circumstances. At that time, the only important criterion was taken as the basis for simplified business planning before industrial allocation: it was economic efficiency, taking into account primarily the value of the resources, the scarcity of materials, equipment, and technology. Official managers, who made all the decisions, sometimes did not have a choice between more or less profitable options for allocation, in view of the threat from outside, expansionism, militarization of the economy, the "Iron Curtain", and the country's economic isolation. Production was placed just anywhere the scarce resources were found (for example, the Norilsk metallurgy complex was built in the Extreme North).

Now it is difficult to say definitely what the main purpose of the Gulag was. But it certainly was not created just to exploit Siberian resources. The first labor camps, which became the basis for a further Gulag system, appeared in accordance with the decree issued by the Central Executive Committee back in 1919 (Dekret VTCIK, 1919).

However, the whole territory of Siberia was not even controlled by the Soviets by that time during the Russian Civil War. Moreover, the first large labor camp (the SLON) was created in 1923 on the Solovky Islands (Istorija SLON, 2009). The location is in the North, but to the north of Europe, and there are no resources there. Thus we assume that the main purposes of the Gulag were terror and repression. Economic practicality of such a system of forced labor was very low. For example, the head of the Gulag, Victor Nasedkin, wrote in 1941: "A comparison of the cost of agricultural production in labor camps and collective farms of the USSR showed that the cost of production in the camps greatly exceeds the collective farms".

State-monopoly direct allocation did not pay much attention to two serious kinds of constraints, which led to some of the current problems. The first one is the ecological constraint. Even the environment was considered to be state-owned and permitting to do anything with it. Ivan Michurin’s agricultural rule, "We can not wait for benefits from nature, it is our objective to take them from it," was taken as a slogan for the industry, but it was given a distorted sense. The second one is the demographic constraint. This constraint was not taken into account because the Soviet government had a large mobilized army of their own "slaves", who were sent to work in various parts of the Soviet Union, whether to the North, Central Russia, Central Asia, the Urals, Siberia, the Volga region, or the Far East.

The Gulag was definitely used for the development of waste regions (a fact strongly underlined by the American authors), but this was more a consequence than a cause. Resolution of the Sovnarkom ordered the OGPU to establish new camps for the intake of prisoners in remote areas for the colonization of these areas and the exploitation of their natural resources only in 1929. It is not surprising that the prisons in Russia are still called labor settlements and colonies. But the labor army of the Gulag was often refilled by people very loyal to the regime, and the length of imprisonment had a tendency to spontaneously increase during 1930s. In 1938, Stalin declared, speaking at a meeting of the Presidium of the Supreme Soviet of the USSR about the existing practice of early release of some prisoners in reward for excellent work: "We do badly; we disturb the labor camps activity. Exemption to these people certainly is need, but in terms of the state economy it is bad [...]" Everything is said clearly there, by the first person of the country, to characterize the system. 
The authors do not try to justify the criminal actions of the Stalinist regime in any case, but only want to characterize the macroeconomic environment in which industrialization and the widespread allocation of production proceeded.

Today Russia is falling into a depression trap between the countries of the Pacific Rim gaining strength and the European Union, particularly the recently admitted Eastern European countries. These countries had been developing more steadily from the beginning of 1990s to the end of 2000s, until the recent global economic crisis began. They are moving along the world development vectors, leaving Russia in the periphery. Also two major regional problematic trends became acute in the late 1990s. These were deindustrialization and the crisis of socialism.

The deindustrialization took place in Russia, rushing like an avalanche and leaving just closed enterprises and new supermarkets behind, but not giving anything else in return. Perhaps only Moscow managed to adapt quickly and develop the service sector. This was achieved by the active participation of foreign investment and a new round of resources centralization since the early 2000s. But various recent attempts of modernization development by high technologies cannot be fully successful in a highly competitive global market outside, and with strong corruption inside.

The crisis of socialism led to mass poverty. It posed the eternal question for regional policy: to support the regions or to help people directly? 1990s' experience showed that the variant "not to help anyone" leads only to a dead end. The government realized that, but was trying to help only a few regions and to support the modest social guarantees for the people. All these measures are still not sufficiently effective. It creates the impression, particularly among the Siberian people, that they are in fact treated like a colony, with the most of taxes and resources taken, and just some charities given from time to time. Population decline in many provincial areas and the overgrowth of Moscow just cause more and more problems both in the province and in Moscow itself. For example, the Magadan region and the Chukotka autonomous district (the most severe and far areas in Russia) lost about 50\% of theirs population in 1990s.

But, in our opinion, if some people want to move from Siberia to other more favorable places, or to come back to their native land from which they came for work, the state must supply them with adequate subsidies and help to minimize the bureaucracy associated with a change of residence. But if people want to continue living, even in severe climate, at least until retirement age, where they have a relatively high income and a stable job, it is necessary to support such intentions, too. Therefore, along with subsidies for resettlement, the rest should be well supplied to ensure a high standard of living of the limited number of people, even in the severe climate of remote areas, if it could benefit the national economy.

The limited number of people could be considered as the widespread development of the shift method. And it is reasonable to hire shift workers from large cities in southern Siberia, because it is easier for them to adapt to the severe northern conditions than for the immigrants from warmer regions. The limited period of the shift, caused by severe climate or difficulty of access, in addition to high wages, may encourage greater intensity of labor. This gives higher labor productivity in turn.

Ivan Pososhkov, a $18^{\text {th }}$ century economist, said that a country is rich only if rich people live there, but if there are miserable people, the country cannot be considered s rich. Russia needs a clearly expressed and financially supported regional development policy to develop 
modern post-industrial economy and to improve life quality of people. Our country does not need to be a kind of superpower any more; it just should be a nice place to visit and to live, watching children growing healthy and safe.

\section{References}

Dekret VTCIK o lageryakh prinuditel'nykh rabot 17.05.1919 (electronic resource), http://www.libussr. ru/doc_ussr/ussr_458.htm

Gaddy C., Hill F., 2003, The Siberian Curse: How Communist Planners Left Russia Out in the Cold. Brookings Institution Press, Washington D.C.

Istorija SLON, NIC “Memorial” Sankt-Peterburg (electronic resource), Mode of access: http://memorial-nic.org/solovki.html

Lamin V.A., Malov V.Yu., 2005, Problem regions of resource type: Asian part of Russia. Integration projects of SB RAS, vol. 4.

\section{Siberian regional policy: the past and modern problems}

The regional development of Siberia faces some difficulties nowadays and they are thought to be the result of historical development. According to American authors, Clifford Gaddy and Fiona Hill ("The Siberian Curse"), as well as some Russian scientists, such problems stem from the period of Soviet abusive colonization of Siberia, or even earlier - from the period of monarchy. But it is essentially hard to realize the situation of Siberia from the perspective of Moscow, let alone from abroad. It is also difficult to imagine the huge differences in territorial proportions, contrasts in Siberian regions, and distances between cities. So it is not acceptable to use non-geographical, dot methods in solving regional problems of Siberia. In fact, the regional problems are very complicated and multilateral, and we should study them with an open mind. Development of Siberia, the Eastern and Northern territories, was not something special in Soviet times. It was based on the whole country large-scale development plans and strategic objectives.

Mgr Ivan Blinov

Irkutsk State Transport University, Russia

e-mail: 1blin4ik@gmail.com 